DOI https://doi.org/10.30525/978-9934-26-000-1-19

\title{
ВІЗУАЛЬНА МАНІПУЛЯЦІЯ «МІСЦЕМ ВЕДУЧОГО» У ПРОГРАМАХ М. МИХАЛКОВА БЕСОГОН ТV
}

\author{
Джиджора С. В. \\ доктор філологічних наук, \\ дочент кафедри періодичної преси та медіаредагування \\ Одеський наиіональний університет імені I. І. Мечникова \\ м. Одеса, Україна
}

3-поміж численних форм маніпуляції суспільною свідомістю окреме місце займають форми візуальної сугестії. Традиційно при створенні популярного ток-шоу, відеоблогу чи телепрограми авторисценаристи приділяють серйозну увагу оформленню візуального ряду. Враховується не тільки, хто буде в кадрі, але й як виглядатимуть спікери, у що буде вбраний ведучий, який інтер'єр буде навколо його робочого місця, як буде виставлене світло, як падатимуть тіні, 3 яких ракурсів працюватимуть камери та багато інших дрібних, але не менш важливих, деталей [більше: $3 ; 4 ; 7]$.

Ретельно продуманий інтер'єр «місця ведучого» й у відомій програмі російського кінорежисера Микити Михалкова «Бесогон TV». Ця програма виходить з 2011 р. і на листопад 2020 в іiї архіві налічується вже 186 випусків, а для популяризації цього медіапродукту створений однойменний сайт [1] та YouTube канал [2]. Раніше «Бесогон TV» виходив на загальнонаціональному російському телеканалі «Россия 24», однак його випуски неодноразово знімалися з ефіру через скандальні висловлювання ведучого (власне, після одного такого інциденту 3 керівництвом програма й «переїхала» на YouTube-платформу). 3 функціональної точки зору, «БесогонТV»- відеоблог з одним постійно діючим ведучим-моралізатором. Основна проблематика його напрочуд емоційних артистичних монологів - глобальні геополітичні та загальнокультурні тенденції сьогодення, звісно, з особливим акцентом на духовних проблемах сучасної Росії, iї «потерпання» від світового закулісся тощо (теми останніх програм: в чому небезпека надмірних амбіцій Навального, загрози європейської мультикультурності, як і для чого Захід спонсорує громадянські організації в Росії). 3 точки ж зору комунікативних ефектів, контент програми носить відверто провокативно-пропагандистський характер $\mathrm{i}$ розрахований на непримириму радикально-русофільську цільову аудиторію.

Особливо не вдаючись до аналізу змістового наповнення випусків програми, зосередимося на організації «робочого місця» ведучого. Як можна переконатися із візуального ряду, М. Михалков веде програму 
сидячи за одним і тим самим письмовим столом в робочому кабінету. Судячи із різноманітних інтерв'ю, це - лише один із робочих кабінетів кінорежисера, але не той основний, що знаходиться у головного маєтку родини Михалкових [5]. У випусках «БесогонTV» ми бачимо край довгого та широкого стола із специфічним декором. На передньому плані - триколор, настільний прапор РФ. Перед ведучим, як правило, розкладені аркуші паперу, теки або книги, необхідні під час програми. За лівим плечем ведучого - два стаціонарні телефони на підставці, білий та чорний. Ще далі, вже не на столі, а на книжкових полицях, одразу три жовті телефони, які зазвичай використовуються в урядових кабінетах для швидкого й прямого спецзв'язку з високопосадовцями. По праву руку М. Михалкова, на підвіконні, вишикувані бронзові бюсти видатних діячів Російської імперії XIX ст. Серед них можна впізнати й імператорів Олександра II та Олександра III, епоху правління яких М. Михалков неодноразово відтворював у своїх стрічках (зокрема, «Сибірський цирульник», «Статський радник»). За спиною ведучого ми бачимо чимало православних ікон у дорогих оздоблених окладах. Це й ікона Св. Трійці (прямо над кріслом), ікона архангела Михаїла (в куті, біля ікони Св. Трійці), ікона св. Серафіма Саровського (за спецтелефоном), численні богородичні ікони, зокрема «Покров Богородиці». Час від часу, коли камера від'іжджає трохи ліворуч, ми можемо бачити, що поряд 3 православними іконами на стіні висять портрети президента РФ В. Путіна. А ще далі - фотографії самого Михалкова, в тому числі й разом $з$ Путіним та церковними ієрархами. Сам ведучий сидить у високому дерев'яно-полакованому кріслі зі шкіряними вставками i, неодмінно пов'язаний шаликом, має досить імпозантний вигляд.

Якщо подивитися на описаний інтер'єр «робочого місця» М. Михалкова очима його цільової аудиторії, то можна зрозуміти, який потужний візуальний вплив на свідомість глядачів здійснює така відеокартинка. Відомий діяч російської культури проголошує себе екзерцистом (з грец. - «той, хто вигоняє диявола»). Відтак його телепрограма має точну й відверту назву - Бесогон, адже головне гасло, 3 яким знайомляться відвідувачі сайту звучить так: «Якщо ти віруєш у Бога, ти маєш повірити і в бісів. Вони є. Я їх бачу» [1]. А де ж виганяти бісів, як не у такому робочому кабінеті, який більше схожий на домашній / офісний храм? I розкішне високе крісло виглядає доречно, адже його власник, освячений християнськими святинями та під пильним наглядом, з одного боку, колишніх російських імператорів, а 3 другого сучасного господаря Росії, представленого явно на фото i неявно у телефонах спецзв'язку, немов на церковному амвоні. Звісно, пересічний глядач не знає справжнього призначення жовтих телефонів в кабінеті ведучого. Може, М. Михалков по ним спілкується із своїм водієм, або кухарем. Однак їхня наявність в кадрі справляє на нього вагоме значення. Адже звичайні люди такими телефонами не користуються! 
Тож телефони, крісло-трон, бюсти, ікони, фото - все вказує на те, що автор програми - вельми статусна особа, близька до сильної та справедливої влади. Але при цьому - ще й справжній поборник православної віри. Такий «знає, що говорить», його джерела надійні, а дух істинний. Саме такі емоційні відгуки й залишають симпатики у коментарях під відео на YouTube-каналі «БесогонTV». Особливо показова реакція під останніми випусками. Зокрема, 186 випуску «Клубок друзів», де М. Михалков показав та потім прокоментував, як В. Путін за допомогою відеозв'язку привітав його із 75-літтям та нагородив Зіркою героя праці РФ, дистанційно (бо й у Кремлі карантин!) піднявши келих шампанського за його здоров'я [6].

3 іншого боку, герменевтичне зчитування статусу особи шляхом аналізу іï часопростору дозволяе побачити специфічні комунікативні зв'язки, що утворилися між ведучим «Бесогону», його аудиторією та владою, явно / неявно проявленою у програмі. У спеціально облаштованій «бесогонній студії» підготовлений глядач бачить традиційне втілення сучасного російського світоукладу: лідер нації уповноважує авторитетного діяча російської культури розтлумачити складні процеси простим людям. Класична ієрархічна структура авторитарної моделі в дії: вождь (Путін на фото і в телефонах «не масового користування») посвячені (Михалков у кріслі) - маси (вдячні глядачі). В іншому історичному контексті ця модель могла б мати ще більш вульгарне втілення: недосяжний цар-батюшка - добрий пан - слухняні холопи.

В організації візуального ряду програми «БесогонТV» яскраво виражена маніпуляція робочим місцем ведучого. У формуванні ставлення глядачів до обговорюваних у програмах проблем інтер'єр кабінету Михалкова відіграє ключову роль. Православно, монархічно, пропутінськи орієнтована аудиторія легко впізнає визначальні для себе просторові маркери. Відповідно ведучий спекулює на релігійній та політичній ідеології, видаючи власні повчальні або викривальні інтерпретації за умовисновки православних / імперськи мислячих людей. Спекуляція проявляється у демонстрації свого віросповідування та хизуванні близьким знайомством із главою держави. Звісно, М. Михалков не журналіст, а його команда, яка працює над «БесогонTV», не репортерський відділ. Тож вони не зобов'язані дотримуватися журналістських стандартів. Але саме з цієї причини випуски програми записуються у такій професійно продуманій «студії»!

\section{Література:}

1. БесогонТВ [офіційний сайт] // https://besogontv.ru/.

2. БесогонTV [YouYube канал] // https://www.youtube.com/channel/ UCiwIy5q59aD-Nph5f-Zvp2A.

3. Брайант Дж, Томпсон С. Основы воздействия СМИ, пер с англ. М. : Издательский дом «Вильямс», 2004. 432 с. 
4. Гібридна війна: технології сугестії та контрсугестії : монографія / О. Акульшин, О.Заруба, Л. Компанцева, С. Кудінов, Н. Слухай, О. Снитко. К. : Нац. Академія СБУ, 2018. 236 с.

5. Гузяева Ю. Дом или домострой: как выглядит родовое поместье Никиты Михалкова // https://housechief.ru/dom-nikity-mihalkovafoto.html.

6. «Клубок друзей», выпуск 186 / БесогонТV // https://www.youtube.com/watch?v=3CtQm314bRQ.

7. Ткаченко И. В. Стоп! Как остановить манипулятора. Как распознать и остановить манипулятора. Х. : Виват, 2014. 224 с. 